\title{
Role of Phosphorylation of Alzheimer's Amyloid Precursor Protein during Neuronal Differentiation
}

\author{
Kanae Ando, ${ }^{1}$ Masaki Oishi, ${ }^{2}$ Shizu Takeda, ${ }^{1,3}$ Ko-ichi lijima, ${ }^{1}$ Toshio Isohara, ${ }^{2,4}$ Angus C. Nairn, ${ }^{2}$ \\ Yutaka Kirino, ${ }^{1}$ Paul Greengard, ${ }^{2}$ and Toshiharu Suzuki ${ }^{1}$ \\ ${ }^{1}$ Laboratory of Neurobiophysics, School of Pharmaceutical Sciences, The University of Tokyo, Hongo 7-3-1, Bunkyo-ku, \\ Tokyo, 113-0033 Japan, 2Laboratory of Molecular and Cellular Neuroscience, The Rockefeller University, New York, New \\ York, 10021, 3Bio-oriented Technology Research Advancement Institution, Toranomon 3-18-19, Minato-ku, Tokyo 105- \\ 0001, Japan, and ${ }^{4}$ Life Science Research Center, Advanced Technology Research Laboratories, Nippon Steel \\ Corporation, 3-35-1 Ida, Nakahara-ku, Kawasaki 211-0035, Japan
}

Alzheimer's amyloid precursor protein (APP), the precursor of $\beta$-amyloid $(A \beta)$, is an integral membrane protein with a receptor-like structure. We recently demonstrated that the mature APP (mAPP; N- and O-glycosylated form) is phosphorylated at Thr668 (numbering for APP695 isoform), specifically in neurons. Phosphorylation of mAPP appears to occur during, and after, neuronal differentiation. Here we report that the phosphorylation of mAPP begins 48-72 hr after treatment of PC12 cells with NGF and that this correlates with the timing of neurite outgrowth. The phosphorylated form of APP is distributed in neurites and mostly in the growth cones of differentiating PC12 cells. PC12 cells stably expressing APP with Thr668Glu substitution showed remarkably reduced neurite extension after treatment with NGF. These observations suggest that the phosphorylated form of APP may play an important role in neurite outgrowth of differentiating neurons.

Key words: Alzheimer's disease; amyloid precursor protein; neurite outgrowth; protein phosphorylation; PC12 cells; neuronal differentiation
Deposition and accumulation of $\beta$-amyloid $(\mathrm{A} \beta)$ in the brain and cerebral blood vessels are characteristic of the pathology of Alzheimer's disease (AD). $\mathrm{A} \beta$ is generated from a larger precursor protein, Alzheimer's amyloid precursor protein (APP) (Goldgaber et al., 1987; Kang et al., 1987; Robakis et al., 1987; Tanzi et al., 1987, 1988; Kitaguchi et al., 1988; Ponte et al., 1988; De Sauvage and Octave, 1989), by proteolytic cleavage (for review, see Price et al., 1998). APP is an integral membrane protein that is phosphorylated in the cytoplasmic (Suzuki et al., 1994; Oishi et al., 1997; Iijima et al., 1998) and extracellular (Hung and Selkoe, 1994; Walter et al., 1997) domains. It has been reported that cell-surface APP plays a role in neurite extension of primary cultured hippocampal neurons (Qiu et al., 1995). The large extracellular domain of APP is also reported to bind extracellular matrix molecules such as heparin (Schubert et al., 1989), laminin (Kibbey et al., 1993), and collagen (Beher et al., 1996), which can mediate cell adhesion and neurite outgrowth. Furthermore, neurite outgrowth has been reported to be inhibited by downregulation of APP expression (Allinquant et al., 1995). These previous reports suggest that the membrane-associated APP affects cell adhesion and neurite outgrowth via an intracellular signal transduction pathway, although the exact molecular mechanism of the biological role of APP is yet to be resolved.

\footnotetext{
Received Dec. 8, 1998; revised March 10, 1999; accepted March 11, 1999.
}

This work was supported in part by a grant from The Program for Promotion of Basic Research Activities for Innovative Biosciences Japan (T.S.) and United States Public Health Service Grant AG09464 (A.C.N., P.G.). K.A. is a recipient of Japan Society for the Promotion of Science (JSPS) Research Fellowships for Young Scientists. K. Ando thanks Y. Suzuki, T. Inoue (University of Tokyo), and Dr. T. Seki (Juntendo University) for technical advice.

Correspondence should be addressed to Toshiharu Suzuki, Laboratory of Neurobiophysics, School of Pharmaceutical Sciences, The University of Tokyo, Hongo 7-3-1, Bunkyo-ku, Tokyo, 113-0033 Japan.

Copyright () 1999 Society for Neuroscience 0270-6474/99/194421-07\$05.00/0
One of the mechanisms that regulates APP function is likely to be protein phosphorylation (for review, see Gandy et al., 1991). Using cultured cell lines, we reported previously that Cdc2 kinase phosphorylates the cytoplasmic domain of APP at Thr668 (numbering for the APP695 isoform) during the G2/M phase of the cell cycle (Suzuki et al., 1994, 1997). Our recent studies demonstrated in adult rat brain that Thr668 of APP is also phosphorylated (Oishi et al., 1997) and that this is mediated by Cdk5, a neuronal homolog of Cdc2 (K. Iijima, Y. Satoh, K. Ando, T. Seki, Y. Arai, P. Greengard, A. C. Nairn, Y. Kirino, and T. Suzuki, unpublished observation). Furthermore, we have found that phosphorylated APP, consisting of mature APP (mAPP; N- and O-glycosylated isoform) but not immature APP (imAPP; $\mathrm{N}$-glycosylated isoform), is largely localized on the plasma membrane of cell bodies and neurites of mature neurons (K. Iijima, Y. Satoh, K. Ando, T. Seki, Y. Arai, P. Greengard, A. C. Nairn, Y. Kirino, and T. Suzuki, unpublished observation). Here we explore the function of the phosphorylation of APP695 at Thr668 during neuronal differentiation of PC12 cells. We find that the phosphorylation of APP at Thr668 begins when the cells start to elaborate minor processes and that phosphorylation increases in parallel with neuronal differentiation. Cells that express a mutant APP with an acidic amino acid in place of Thr668 exhibit reduced neurite extension after stimulation to differentiate. These observations suggest that the phosphorylation of APP may play an important role in neuronal differentiation.

\section{MATERIALS AND METHODS}

Antibodies. Polyclonal anti-APP antibody (AbAPP) UT-421 was prepared against a peptide [Cys]APP ${ }^{676-695}$ of APP695 (Tomita et al., 1998a). Polyclonal phosphorylation state-specific antibody (pAbThr668) UT-33 was raised against a phosphopeptide $\mathrm{APP}^{665-673}$ [Cys][PiThr668] of APP695, synthesized at Quality Controlled Biochemicals (Hopkinton, 
MA). The specificity of UT-33 for the phosphorylated form of APP was similar to that of pAbThr668 G-474 (Oishi et al., 1997). UT-33 does not cross-react with the dephosphorylated APP, APP ${ }^{645-694}$ of APP695, or with other proteins from rat brain tissues (K. Iijima, Y. Satoh, K. Ando, T. Seki, Y. Arai, P. Greengard, A.C. Nairn, Y. Kirino, and T. Suzuki, unpublished observation). Antibodies were affinity-purified using antigen peptide. Anti- $\alpha$-tubulin monoclonal antibody TU-01 (Zymed Lab, South San Francisco, CA), anti-tubulin polyclonal antibody T-3526 (Sigma, St. Louis, MO), and anti-FLAG monoclonal antibody M2 (Eastman Kodak, New Haven, CT) were purchased.

Plasmid construction. cDNA encoding human APP695 (Kang et al., 1987) was prepared as described previously (Tomita et al., 1998a). The phosphorylation site Thr668 was mutated to Ala or Glu to produce pAPP695T668A (Thr to Ala mutation at amino acid position 668) and pAPP695T668E (Thr to Glu mutation at amino acid position 668) as described (Tomita et al., 1998b). The FLAG sequence was produced by PCR using primers 5'-TAATACGACTCACTATAGGG-3' (forward) and 3'-CGGACCTGCCGAGCCCGCCTGATGTTCCTACTGCTACT GTTCGACC TCCATGGGTG-5' (reverse, the underlined nucleotides encode the FLAG sequence DYKDDDDK, and the nucleotides in italics represent a KpnI site) and inserted between APP695Ala17 and APP695Leu18 of APP695 cDNA in pcDNA3 (pAPP695NFLAG). The EcoRI-XhoI fragment of pAPP695NFLAG including APP695 ${ }^{606-695}$ was exchanged for an identical fragment from pAPP695T668A or pAPP695T668E (Tomita et al., 1998b) to produce pAPP695NFLAGT668A or pAPP695NFLAGT668E.

Cell culture and production of PC12 cell lines that stably express FLAGtagged APP. PC12, rat adrenal pheochromocytoma cells, were cultured in DMEM (Life Technologies, Gaithersburg, MD) containing 10\% (v/v) heat-inactivated fetal bovine serum (Iansa) and $5 \%(\mathrm{v} / \mathrm{v})$ heatinactivated horse serum (Life Technologies). For induction of neuronal differentiation, the cells were treated with NGF (Seikagaku, Tokyo, Japan) at $50 \mathrm{ng} / \mathrm{ml}$ for various times as indicated. The medium was changed every $2 \mathrm{~d}$, and fresh NGF was added each time. PC12 cells were transfected with plasmid DNA for the various constructs using LipofectAMINE reagent (Life Technologies), and several independent clones stably expressing the exogenous APP were isolated. No major differences were found in the levels of expression of the three forms of fAPP695 used in this study.

Detection of total APP and of APP phosphorylated at Thr668. PC12 cells were harvested at the indicated time after administration of NGF. APP was recovered from the cell lysate by immunoprecipitation with UT-421 as described (Suzuki et al., 1994; Oishi et al., 1997). Immunoprecipitates were subjected to SDS-PAGE [6\% (w/v) polyacrylamide] and electrophoretically transferred to nitrocellulose membranes. The membrane was incubated with UT-421 or UT-33 and then with $\left[{ }^{125} \mathrm{I}\right]$-protein A (Amersham Pharmacia Biotech, Buckinghamshire, UK). Radioactivity was quantified using a Fuji BAS 2000 imaging analyzer (Fuji Photo Film, Tokyo, Japan).

Immunocytochemical staining of cells. PC12 cells $\left(\sim 2-3 \times 10^{4}\right)$ were cultured on $35 \mathrm{~mm}$ glass-bottom dishes (Mat Tek, Ashland, MA) and treated without or with NGF for various times. Cells were fixed in $4 \%$ $(\mathrm{w} / \mathrm{v})$ paraformaldehyde in PBS containing $4 \%(\mathrm{w} / \mathrm{v})$ sucrose for $10 \mathrm{~min}$ at room temperature and permeabilized with $0.1 \%(\mathrm{v} / \mathrm{v})$ Triton X-100 in PBS (10 mm sodium phosphate, $\mathrm{pH} 7.2,140 \mathrm{~mm} \mathrm{NaCl})$ for $5 \mathrm{~min}$. The cells were rinsed with PBS, incubated with affinity-purified antibody overnight at $4^{\circ} \mathrm{C}$, followed by incubation with fluorescein isothiocyanate (FITC)- or tetramethylrhodamine B isothiocyanate (TRITC)-conjugated secondary antibody (Zymed Lab). Scanning fluorescent images were analyzed using a Bio-Rad MRC 600 confocal laser scanning microscope (Bio-Rad, Hercules, CA).

\section{RESULTS}

\section{Phosphorylation of APP at Thr668 correlates with differentiation of PC12 cells}

The mAPP is specifically phosphorylated in neuronal tissues of the adult rat and in primary cultured hippocampal neurons prepared from the E18 embryo of rat (Oishi et al., 1997; Iijima, Satoh, Ando, Seki, Arai, Greengard, Nairn, Kirino, and Suzuki, unpublished observation). However, it is unclear at what time during neuronal cell differentiation the phosphorylation of APP at Thr668 begins. To resolve this issue, we examined phosphorylation of APP during neuronal differentiation using rat pheo-
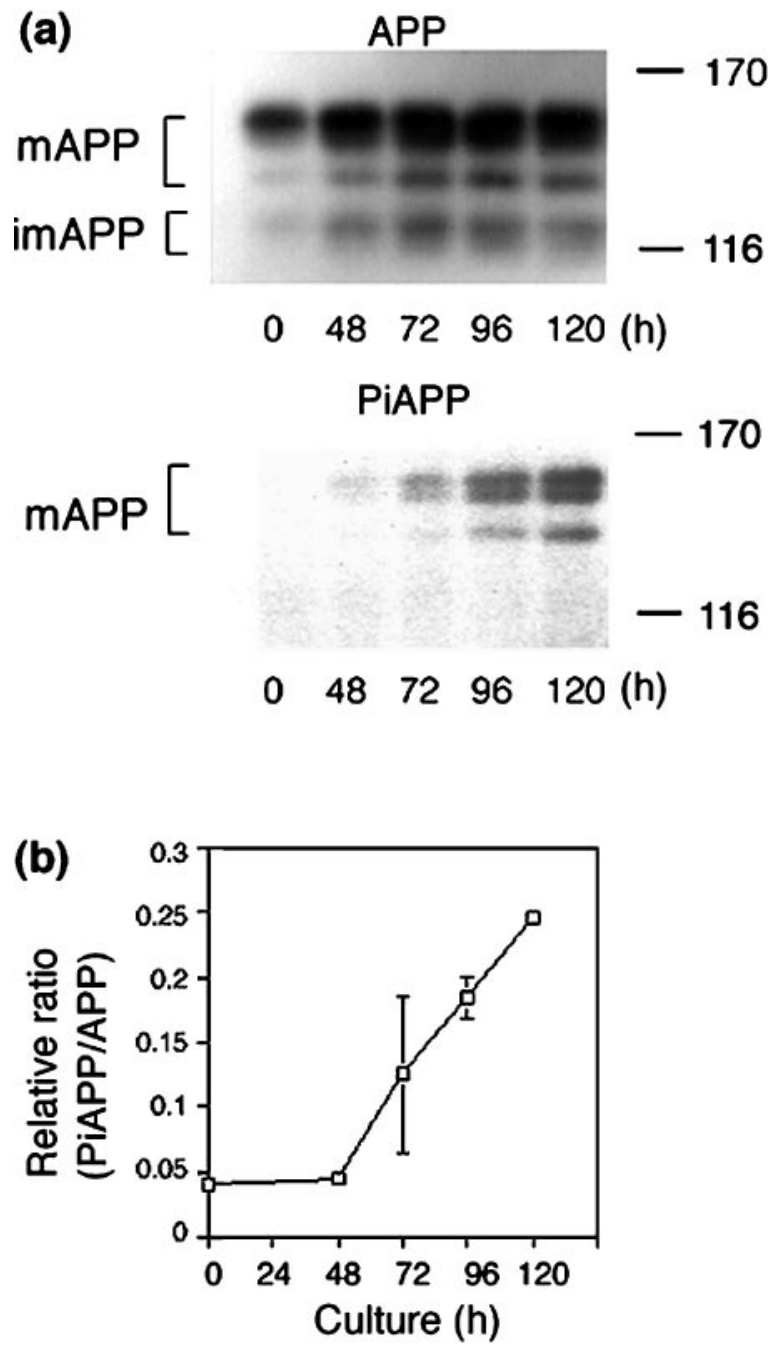

Figure 1. Phosphorylation of APP at Thr668 during neuronal differentiation of PC12 cells. PC12 cells $\left(\sim 1 \times 10^{6}\right.$ cells $)$ were cultured in the presence of NGF for the indicated times (0-120 hr). a, APP was immunoprecipitated from cell lysates (1.5 $\mathrm{mg}$ of protein) using UT-421, and samples were analyzed by SDS-PAGE $[6 \%(\mathrm{w} / \mathrm{v})$ polyacrylamide $]$ and Western blotting using either UT-421 (APP, top) or UT-33 (PiAPP, bottom). $b$, APP and PiAPP were quantified using a Fuji BAS 2000 Imaging Analyzer, and the level of PiAPP was normalized to that of APP. The results shown are the average of duplicate assays, and error bars are indicated. $m A P P$, Mature APP isoforms; imAPP, immature APP isoforms. The size of the molecular weight standards (in kilodaltons) is indicated.

chromocytoma PC12 cells. These cells differentiate into sympathetic neuron-like cells in response to NGF (Greene and Tishler, 1976).

PC12 cells were cultured in the presence of NGF for various times. Both the phosphorylated and the dephosphorylated forms of APP were recovered by immunoprecipitation of cell lysates with a polyclonal anti-APP antibody UT-421. The immunoprecipitates were analyzed by immunoblot with UT-421 and with a polyclonal phosphorylation state-specific antibody UT-33 to examine the levels of expression and phosphorylation of APP (Fig. 1). After administration of NGF (0 hr), cells began to extend neurites, accompanied by a gradual increase of APP expression ( $\sim 72 \mathrm{hr}$ ). When cells possessed elongated neurite(s) $(72-120 \mathrm{hr})$ and appeared to be fully differentiated, the intracellular level of 

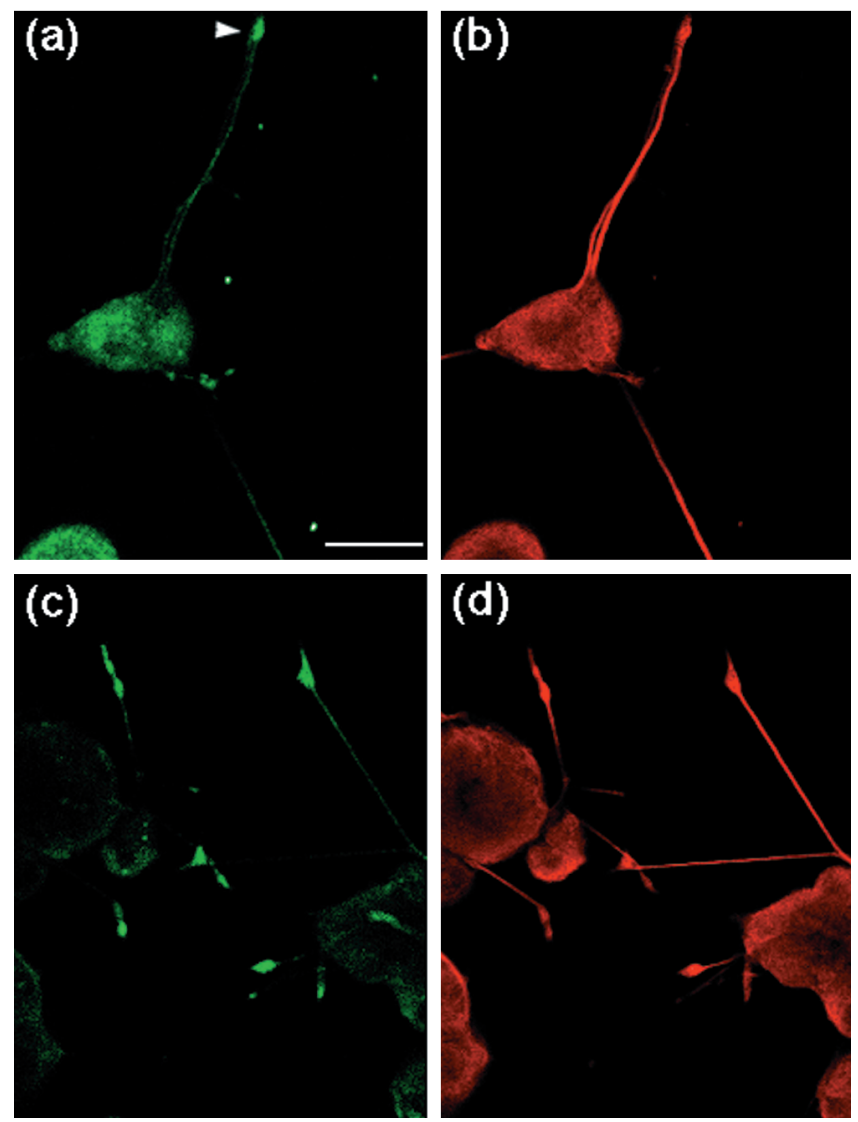

Figure 2. Localization of APP and phosphorylated APP in differentiating PC12 cells. PC12 cells $\sim 2-3 \times 10^{4}$ ) were cultured for $72 \mathrm{hr}$ with NGF. Cells were double-stained with UT-421 $(a)$ and TU-01 $(b)$ antibodies, or double-stained with UT-33 $(c)$ and TU-01 $(d)$. Scale bar, 25 $\mu \mathrm{m}$. Arrowhead indicates a growth cone.

APP no longer increased (Fig. $1 a, A P P$ ). The phosphorylated form of APP at Thr668 (numbering for APP695), or PiAPP, increased dramatically after $48 \mathrm{hr}$ of NGF treatment (Fig. 1a, PiAPP), and the ratio of PiAPP to total APP increased in direct proportion to the progression of differentiation (Fig. 1b). Phosphorylation of APP occurred predominantly in mAPP rather than in imAPP [for characterization of APP species in PC12 cells, see Caporaso et al. (1992)]. When control PC12 cells were cultured in the absence of NGF and harvested at the same time points, the level of the PiAPP was negligible (data not shown). Overall, the results indicate that the phosphorylation of mAPP at Thr668 occurs when neurites are extending during neuronal differentiation.

\section{Localization of phosphorylated APP in differentiated PC12 cells}

As the first step in elucidating the role of the phosphorylation of APP during neuronal differentiation, we examined the localization of PiAPP by immunocytochemical staining of differentiating PC12 cells (Fig. 2). PC12 cells were cultured for $72 \mathrm{hr}$ in the presence of NGF and stained with UT-421 or UT-33 (green fluorescence in Fig. 2a,c). The cells were also double-stained with anti- $\alpha$-tubulin monoclonal antibody TU-01 (red fluorescence in Fig. 2b,d). APP was detected mostly in the cell body and in growth cones (Fig. 2a). APP phosphorylated at Thr668 was distributed sparingly in the cell body, moderately in the neurites, and predominantly in growth cones (Fig. 2c). A similar distribution of

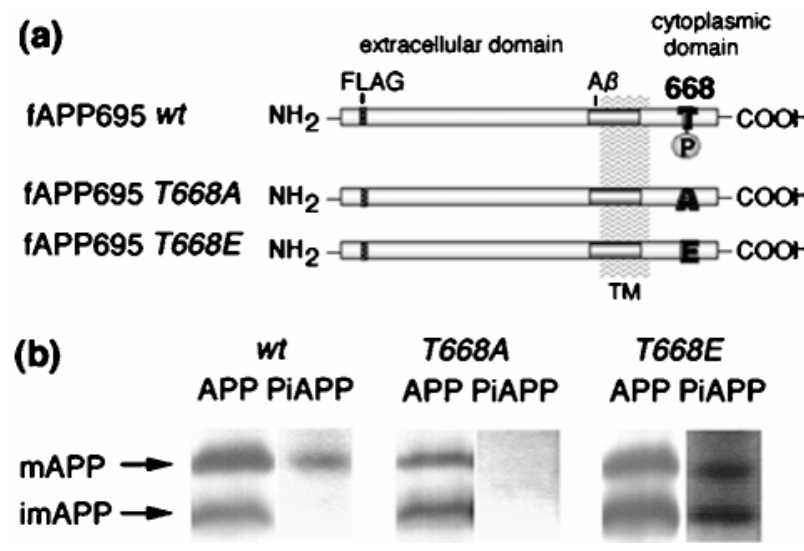

Figure 3. Domain organization of wild-type and mutant fAPP695 molecules and analysis of their expression and phosphorylation in PC12 cells. $a$, The domain organization of fAPP695 is illustrated. The positions of the FLAG sequence $(F L A G)$, the transmembrane domain $(T M)$, the $\beta$-amyloid $(A \beta)$ domain, and the phosphorylation site, T668 (668), are indicated. The mutation of Thr668 is also indicated: in fAPP695T668 A, threonine is replaced by alanine; in fAPP695T668E, threonine is replaced by glutamate. $b$, APP was immunoprecipitated from cell lysates (1.5 mg of protein) from PC12 cells stably expressing fAPP695wt ( $w t)$, fAPP695T668A (T668A) or fAPP695T668E (T668E) using M2 (FLAG) antibody, and the samples were subjected to SDS-PAGE $[6 \%(\mathrm{w} / \mathrm{v})$ polyacrylamide]. Samples were analyzed by Western blot using UT-421 $(A P P)$ and UT-33 $(P i A P P)$ antibodies. Immunocomplexes were detected with ${ }^{125}$ I-protein $\mathrm{A}$, and APP and PiAPP were quantified using a Fuji BAS 2000 Imaging Analyzer. $m A P P$, Mature fAPP695; imAPP, immature fAPP695.

PiAPP was observed in cells as early as $48 \mathrm{hr}$ after NGF treatment, except that the cells possessed shorter neurites (data not shown). When undifferentiated PC12 cells were grown in the absence of NGF, PiAPP was not observed except in cells in the mitotic phase of the cell cycle (K. Ando and T. Suzuki, unpublished observation) as expected from our previous studies (Suzuki et al., 1994; Oishi et al., 1997).

\section{Role of phosphorylation of APP during neuronal differentiation}

The increased level of PiAPP during neuronal differentiation and the predominant localization of PiAPP in growth cones suggest the possibility that APP with a phosphorylated cytoplasmic domain plays an important role in neurite outgrowth. To determine whether the phosphorylation of APP was simply an event occurring after neurite formation or was actually necessary to induce neurite formation, we established several series of PC12 cell lines that stably expressed human APP carrying a single amino acid substitution at the phosphorylation site Thr668. Because PC12 cells express relatively high levels of endogenous APP, we quantified the expression level of exogenous APP by preparing constructs (fAPP695) that contained an eight amino acid FLAG sequence (Fig. 3a). Thr668 of APP was also mutated to Ala (fAPP695T668A) or Glu (fAPP695T668E). Mutation to alanine is expected to mimic the dephosphorylated state of Ser or Thr residues, whereas mutation to glutamate has been found in some cases to mimic the phosphorylated state of Ser or Thr residues (Fong et al., 1989; Waldmann et al., 1990; Mayford et al., 1995). UT-33 recognized fAPP695T668E as well as fAPP695wt phosphorylated at Thr668 but did not recognize fAPP695T668A (Fig. $3 b$ ). As expected, mature but not immature fAPP695wt was detected as a phosphorylated form (Fig. 3b, PiAPP, left panel). Both 

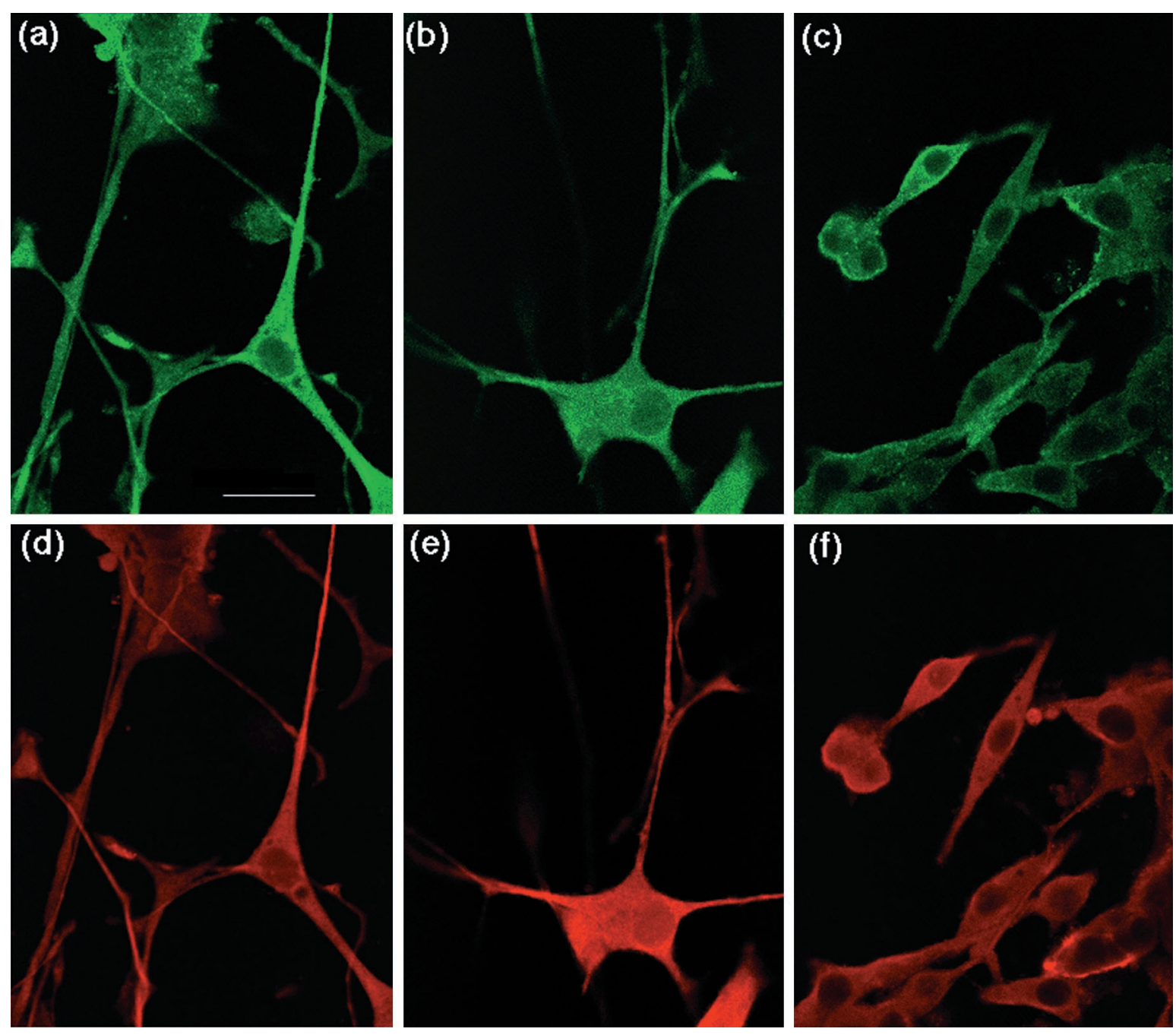

Figure 4. Localization of fAPP695 in PC12 cells after treatment with NGF. PC12 cells stably expressing fAPP695wt (a, $d)$, fAPP695T668A $(b, e)$, and fAPP695T668E $(c, f)$ were treated with NGF for $72 \mathrm{hr}$ and double-stained with M2 (FLAG) $(a-c)$ and T-3526 (tubulin) (d-f) antibodies. Scale bar, 25 $\mu \mathrm{m}$.

immature and mature fAPP695T668E were detected with UT-33 (Fig. 3b, PiAPP, right panel).

PC12 cells, expressing almost identical quantities of the various fAPP695 proteins (Fig. 3b, APP), were differentiated by administration of NGF. The expression of fAPP695 was confirmed by staining cells (Fig. $4 a-c$ ) with anti-FLAG monoclonal antibody. The morphology of the cells was examined by staining with anti-tubulin polyclonal antibody (Fig. $4 d-f$ ). After $72 \mathrm{hr}$ of NGF treatment, PC12 cells expressing fAPP695T668A (Fig. 4b,e) exhibited neurite extension to the same degree as cells expressing fAPP695wt (Fig. 4a,d), indicating normal differentiation. No remarkable difference in the localization of fAPP695 was observed between fAPP695wt and fAPP695T668A in the five independent cell lines examined. Furthermore, Western blot analysis demonstrated that the endogenous APP in PC12 cells expressing fAPP695T668A was phosphorylated normally (data not shown). However, PC12 cells expressing fAPP695T668E elaborated significantly fewer and shorter neurites (Fig. 4c,f).

The number and length of neurites were measured at various time points after the administration of NGF in PC12 cells expressing fAPP695 (Fig. 5). Like nontransfected PC12 cells (PC12), PC12 cells expressing fAPP695wt (wt) began to extend neurites, and the ratio of cells possessing neurites increased after the administration of NGF. Similarly, PC12 cells expressing fAPP695T668A (T668A) extended neurites to the same extent as those expressing fAPP695wt (wt) and the nontransfected PC12 cells (PC12). However, PC12 cells expressing fAPP695T668E possessed only a small number of shorter neurites (T668E). These results indicate that PC12 cells expressing APP carrying the substitution of Glu at the phosphorylation site failed to efficiently extend neurites. The FLAG sequence in APP695 did not interfere with the differentiation of PC12 cells, at least when measured by neurite outgrowth. Identical results were also obtained using PC12 cells that expressed the APP770 isoform containing Thr743 (position 668 of APP695) to alanine or glutamate mutations (data not shown).

The effect of the T668E mutation of APP695 on neurite outgrowth of PC12 cells was further analyzed by examining the expression of MAP5, a marker protein in the growing neurites of differentiating neurons (Brugg and Matus, 1988). MAP5 was detectable in PC12 cells expressing fAPP695wt and fAPP695T668A as early as $24 \mathrm{hr}$, and the level of expression increased in proportion to the culture time. In contrast, PC12 cells expressing fAPP695T668E expressed a low level of MAP5 even at $72 \mathrm{hr}$ 
(a)

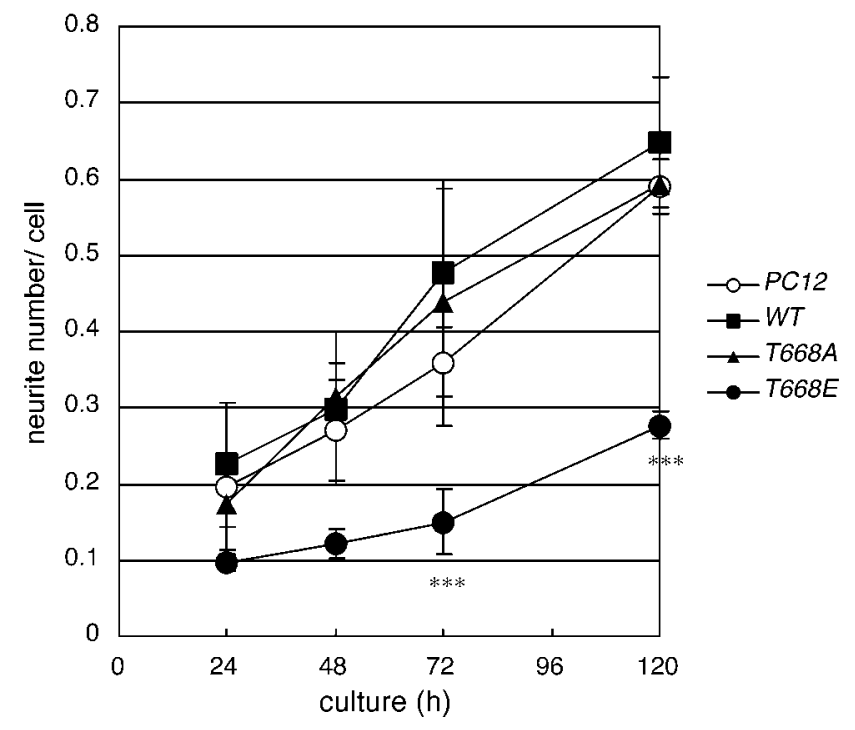

(b)

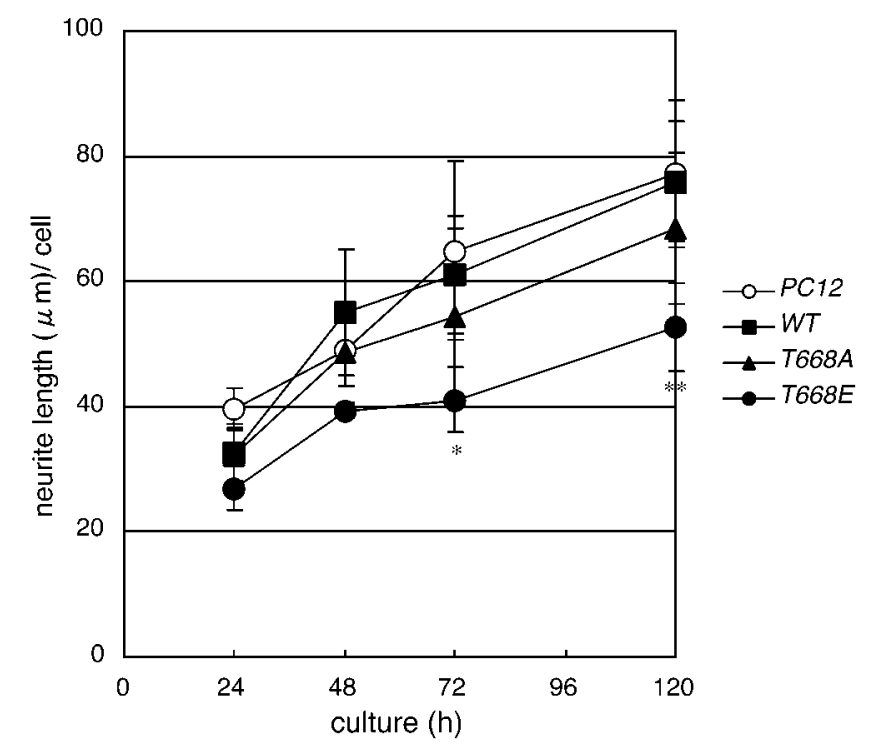

Figure 5. Neurite extension of PC12 cells expressing fAPP695 after treatment with NGF. PC12 cells stably expressing fAPP695wt (WT), fAPP695T668A $(T 668 A)$, or fAPP695T668E (T668E), and nontransfected cells (PC12) were cultured in the presence of NGF for the indicated times. $a$, The numbers of neurites was divided by the cell number examined $(n=100) . b$, The length (in micrometers) of the neurites was measured, and the average length of neurites from 100 cells is indicated. Experiments were performed using five independent clones of cell lines expressing the various constructs, and the averages and SD are shown $(n=5)$. Asterisks indicate statistical significance by standard $t$ test relative to fAPP695wt $\left({ }^{*} p<0.01 ; * * p<0.005 ; * * * p<\right.$ $0.001)$.

(data not shown). The results confirmed that neurite outgrowth was still immature in PC12 cells expressing fAPP695T668E, even after $72 \mathrm{hr}$ of NGF treatment, and agreed with the morphological analysis of the cells (Figs. 4, 5).

\section{DISCUSSION}

APP is thought to be a pathogenic factor in Alzheimer's disease as a result of proteolytic processing of the protein to produce the neurotoxic peptide $\mathrm{A} \beta$ (for review, see Price et al., 1998). In addition, patients with several types of familial AD (FAD) carry a mutation in their APP gene (Levy et al., 1990; Chartier-Harlin et al., 1991; Goate et al., 1991; Murrell et al., 1991). The expression of the APP gene is ubiquitous (Wasco et al., 1993), although neuronal tissues express a tissue-specific isoform, APP695, produced by alternative splicing (Kang et al., 1987). As a result of the widespread occurrence of APP, it has been difficult to identify a neuron-specific function for the protein. Interestingly, APP has a membrane-associated receptor-like structure (Kang et al., 1987), and the cytoplasmic domain of APP is thought to perhaps mediate an as yet undefined signal transduction process that would take place on binding of an extracellular ligand (for review, see Neve, 1996). We recently established that constitutive phosphorylation of the cytoplasmic domain of APP was neuron specific and that this appeared to be the only significant difference between neuronal and non-neuronal APP (Iijima, Satoh, Ando, Seki, Arai, Greengard, Nairn, Kirino, and Suzuki, unpublished observation).

In the present study, we explored the function of the phosphorylation of APP in PC12 cells stimulated to differentiate into a neuron-like phenotype with NGF. PiAPP appeared $\sim 48 \mathrm{hr}$ after the stimulation of neuronal differentiation and was mostly localized in growth cones. The time course of appearance of PiAPP was not specific to PC12 cells, because similar results were obtained using X58 cells, a mouse neuroblastoma-rat strial neuron hybridoma induced to differentiate by treatment with forskolin
(Wainwright et al., 1995) (data not shown). Furthermore, PiAPP was also observed in differentiating fields of embryonic neuronal tissues on neuronal formation but not in undifferentiated neuroepithelium (K. Ando and K. Iijima, unpublished observation). These observations suggest the possibility that PiAPP plays a significant role in neurite outgrowth and/or neuronal differentiation.

There are several reports concerning the relationship between APP and neurite extension (Kibbey et al., 1993; Allinquant et al., 1995; Beher et al., 1996). However, the molecular mechanism(s) involved in the role of membrane-associated APP in neurite extension is not known. In the present study, we observed that mutation of Thr668 to glutamate, but not to alanine, prevented neurite extension. Mutation of APP did not influence the maturation of the protein. In addition, pulse-chase analysis of undifferentiated and differentiated PC12 cells expressing fAPP695wt or fAPP695T668E resulted in the production of similar levels and similar secretion of extracellular amino-terminal domain (sAPP) (data not shown). Therefore, our present observations suggest that membrane-associated mAPP plays a role in neurite extension through the phosphorylation of its cytoplasmic domain but not through the generation of sAPP from APP.

The molecular mechanism by which fAPP695T668E prevents neurite extension in PC12 cells after the addition of NGF is not known. However, a hypothetical model is illustrated in Figure 6. In wild-type cells and cells that express wild-type fAPP695, APP is phosphorylated after differentiation with NGF stimulation, and PiAPP is localized to growth cones. We propose that within growth cones PiAPP may bind to a putative intracellular protein factor and that this interaction would facilitate the attachment of neurites to the tissue culture dish surface and/or the extracellular matrix. Expression of fAPP695T668A would not be expected to interfere with the binding of endogenous PiAPP with the putative 

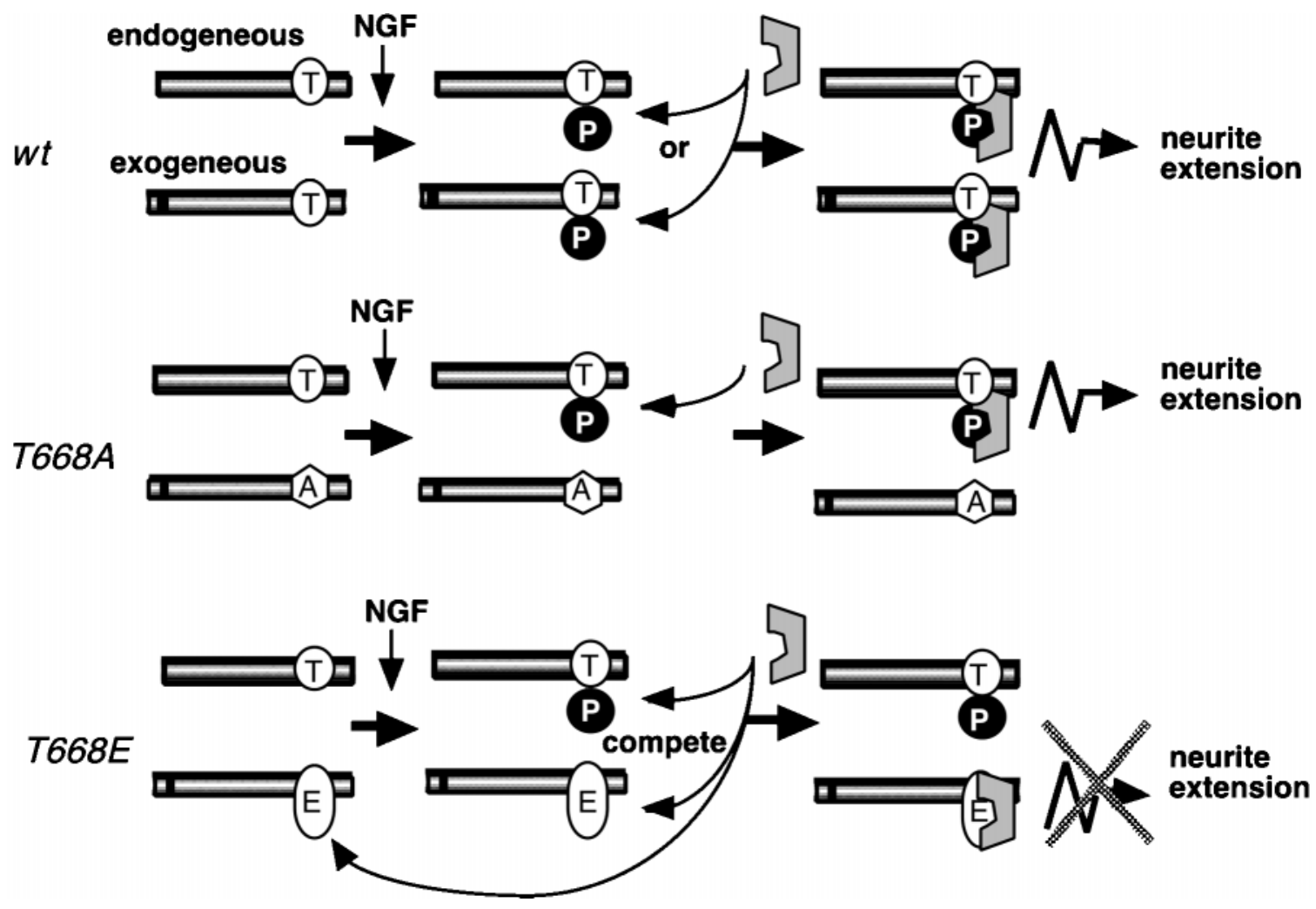

Figure 6. Proposed model for the role of APP, phosphorylated at Thr668, in neurite outgrowth. Endogenous wild-type APP is phosphorylated at Thr668 after incubation with NGF, and PiAPP present in growth cones influences neurite extension via a putative protein factor ( $g$ ray box). Exogenous wild-type APP is also phosphorylated in response to NGF treatment and contributes to normal neurite extension. Exogenous fAPP695T668A (T668A) cannot bind the putative protein, but neurite extension progresses normally by virtue of the interaction of endogenous phosphorylated APP with protein factor. In contrast, exogenous fAPP $695 T 668 E(T 668 E)$ binds the putative protein factor, but this association either initially blocks neurite outgrowth or interferes with normal function of the phospho-APP/protein factor complex by a "dominant negative" effect.

factor and would not influence normal neurite extension. In contrast, mutation of Thr668 to glutamate may result in an APP molecule that competes for binding to the putative factor involved in neurite outgrowth. Undifferentiated PC12 cells expressing fAPP695T668E contain endogenous dephosphorylated APP and a relatively large quantity of fAPP695T668E. After stimulation with NGF, the PC12 cells are presumably committed to differentiate, and phosphorylation of endogenous APP at Thr668 begins to occur. The high levels of fAPP695T668E in the cells either before or after treatment with NGF would compete for the putative factor and interfere with its normal function. This could be caused by the incorrect localization of fAPP695T668E compared with PiAPP within cells or the fact that fAPP695T668E interacts with the putative factor in a manner distinct from PiAPP.

Several proteins have been shown to interact with the cytoplasmic domain of APP, including Fe65, the Fe-65-like protein, X11, an X11-like protein, Go, APP-BP1, PAT1, and UV-DDB (Nishimoto et al., 1993; Fiore et al., 1995; Borg et al., 1996; Chow et al., 1996; Guénette et al., 1996; Duilio et al., 1998; Zheng et al., 1998; Tomita et al., 1999; Watanabe et al., 1999). The binding of Fe65, Fe-65 like, X11, X11-like, and UV-DDB protein to APP is not affected by the mutation of Thr668 to glutamate and alanine (S. Tomita and T. Suzuki, unpublished observation); however, the influence of phosphorylation of Thr668 on the interaction of APP with the other proteins is not known. Further studies to examine these interactions, as well as identification of additional proteins that bind to APP in a phosphorylation-dependent manner, should contribute to our understanding of the role of APP in neuronal differentiation and possibly of the role of APP in the pathogenesis of AD.

\section{REFERENCES}

Allinquant B, Hantraye P, Mailleux P, Moya K, Bouillot C, Prochiantz A (1995) Downregulation of amyloid precursor protein inhibits neurite outgrowth in vitro. J Cell Biol 128:919-927.

Beher D, Hesse L, Masters CL, Multhaup G (1996) Regulation of amyloid protein precursor (APP) binding to collagen and mapping of the binding sites on APP and collagen type 1. J Biol Chem 271:1613-1620.

Borg J-P, Ooi J, Levy E, Margolis B (1996) The phosphotyrosine interaction domain of X11 and Fe65 bind to distinct sites on the YENPTY motif of amyloid precursor protein. Mol Cell Biol 16:6229-6241.

Brugg B, Matus, A (1988) PC12 cells express juvenile microtubleassociated proteins during nerve growth factor-induced neurite outgrowth. J Cell Biol 107:643-650.

Caporaso GL, Gandy SE, Buxbaum JD, Ramabhadran TV, Greengard P (1992) Protein phosphorylation regulates secretion of Alzheimer $\beta / \mathrm{A} 4$ amyloid precursor protein. Proc Natl Acad Sci USA 89:3055-3059.

Chartier-Harlin M-C, Crawford F, Houlden H, Warren A, Hughes D, Fidani L, Goate A, Rosser M, Roques P, Hardy J, Mullan M (1991) Early-onset Alzheimer's disease caused by mutations at codon 717 of the $\beta$-amyloid precursor protein gene. Nature 353:844-846.

Chow N, Korenberg JR, Chen X-N, Neve RL (1996) APP-BP1, a novel protein that binds to the carboxyl-terminal region of the amyloid precursor protein. J Biol Chem 271:11339-11346.

De Sauvage F, Octave JN (1989) A novel mRNA of the A4 amyloid precursor gene coding for a possibly secreted protein. Science 245:651-653.

Duilio A, Faraonio R, Minopoli G, Zambrano N, Russo T (1998) Fe65L2: a new member of the Fe65 protein family interacting with the 
intracellular domain of the Alzheimer's $\beta$-amyloid precursor protein. Biochem J 330:513-519.

Fiore F, Zambrano N, Minopoli G, Donini V, Duilio A, Russo T (1995) The regions of the Fe65 protein homologous to the phosphotyrosine interaction/phosphotyrosine binding domain of Shc bind the intracellular domain of the Alzheimer's amyloid precursor protein. J Biol Chem 270:30853-30856.

Fong YL, Taylor WL, Means AR, Soderling TR (1989) Studies of the regulatory mechanism of $\mathrm{Ca}^{2+} /$ calmodulin-dependent protein kinase 2. J Biol Chem 264:16759-16763.

Gandy SE, Buxbaum JD, Greengard P (1991) Signal transduction and the pathobiology of Alzheimer's disease. In: Alzheimer's disease (Iqbal K, Crapper-McLachlan D, Winblad B, Wisniewski HM, eds), pp 155172. New York: Wiley.

Goate A, Chartier-Harlin M-C, Mullan M, Brown J, Crawford F, Fidani L, Giuffra J, Haynes A, Irving N, James L, Mant R, Newton P, Rooke K, Roques P, Talbot C, Pericak-Vance M, Roses A, Williamson R, Rossor M, Owen M, Hardy J (1991) Segregation of a missense mutation in the amyloid precursor protein gene with familial Alzheimer's disease. Nature 349:704-707.

Goldgaber D, Lerman MI, McBride OW, Saffiotti U, Gajdusek DC (1987) Characterization and chromosomal localization of a cDNA encoding brain amyloid of Alzheimer's disease. Science 235:877-880.

Greene LA, Tishler AS (1976) Establishment of a noradrenergic clonalline of rat adrenal pheochromocytoma cells which respond to nerve growth factor. Proc Natl Acad Sci USA 73:2424-2428.

Guénette SY, Chen J, Jondro PD, Tanzi RE (1996) Association of a novel human FE65-like protein with the cytoplasmic domain of the $\beta$-amyloid precursor protein. Proc Natl Acad Sci USA 93:10832-10837.

Hung AJ, Selkoe DJ (1994) Selective ectodomain phosphorylation and regulated cleavage of $\beta$-amyloid precursor protein. EMBO J 13:534-542.

Iijima K, Lee D-S, Okutsu J, Tomita S, Hirashima N, Kirino Y, Suzuki T (1998) cDNA isolation of Alzheimer's amyloid precursor protein from cholinergic nerve terminals of the electric organ of the electric ray. Biochem J 330:29-33.

Kang J, Lemaire HG, Unterbeck AJ, Salbaum JM, Masters CL, Grzeschik KH, Multhaup G, Beyreuther K, Müller-Hill B (1987) The precursor of Alzheimer's disease amyloid A4 protein resembles a cell-surface receptor. Nature 325:733-736.

Kibbey MC, Jucker M, Weeks BS, Neve RL, Van Nostrand WE, Kleinman HK (1993) $\beta$-Amyloid precursor protein binds to the neuritepromoting IKVAV site of laminin. Proc Natl Acad Sci USA 90:10150-10153.

Kitaguchi N, Takahashi Y, Tokushima Y, Shiojiri S, Ito H (1988) Novel precursor of Alzheimer's disease amyloid protein shows protease inhibitory activity. Nature 331:530-532.

Levy E, Carman MD, Fernandez-Madrid IJ, Power MD, Lieberburg E, van Duinen SG, Bots GTAM, Luyendijk W, Frangione B (1990) Mutation of the Alzheimer's disease amyloid gene in hereditary cerebral hemorrhage, Dutch-type. Science 248:1124-1126.

Mayford M, Wang J, Kandel ER, O'Dell TJ (1995) CaMKII regulates the frequency-response function of hippocampal synapses for the production of both LTD and LTP. Cell 81:891-904.

Murrell J, Farlow M, Ghetti B, Venson MD (1991) A mutation in the amyloid precursor protein associated with hereditary Alzheimer's disease. Science 254:87-99.

Neve RL (1996) Mixed signals in Alzheimer's disease. Trends Neurosci 19:371-372.

Nishimoto I, Okamoto T, Matsuura Y, Takahashi S, Okamoto T, Murayama Y, Ogata E (1993) Alzheimer amyloid protein precursor complexes with brain GTP-binding protein G(o). Nature 362:75-79.

Oishi M, Nairn AC, Czernik AJ, Lim GS, Isohara T, Gandy SE, Greengard P, Suzuki T (1997) The cytoplasmic domain of Alzheimer's amyloid precursor protein is phosphorylated at Thr654, Ser655, and Thr668 in adult rat brain and cultured cells. Mol Med 3:111-123.
Ponte P, Gonzalez-DeWhitt P, Schilling J, Miller J, Hsu D, Greenberg B, Davis K, Wallace W, Lieberburg W, Fuller F (1988) A new A4 amyloid mRNA contains a domain homologous to serine proteinase inhibitors. Nature, 331:525-527.

Price DL, Sisodia SS, Borchelt DR (1998) Genetic neurodegenerative disease: the human illness and transgenic models. Science 282:1079-1083.

Qiu WQ, Ferreira A, Miller C, Koo EH, Selkoe DJ (1995) Cell-surface $\beta$-amyloid precursor protein stimulates neurite outgrowth of hippocampal neurons in an isoform-dependent manner. J Neurosci 15:2157-2164.

Robakis NK, Ramakrishna N, Wolfe G, Wisniewski HM (1987) Molecular cloning and characterization of a cDNA encoding the cerebrovascular and the neuritic plaque amyloid peptides. Proc Natl Acad Sci USA 84:4190-4194.

Schubert D, LaCorbiere M, Saitoh T, Cole G (1989) Characterization of an amyloid $\beta$ precursor protein that binds heparin and contains tyrosine sulfate. Proc Natl Acad Sci USA 86:2066-2069.

Suzuki T, Oishi M, Marshak DM, Czernik AJ, Nairn AC, Greengard P (1994) Cell cycle-dependent regulation of the phosphorylation and metabolism of the Alzheimer amyloid precursor protein. EMBO J 13:1114-1122.

Suzuki T, Ando K, Isohara T, Oishi M, Lim GS, Satoh Y, Wasco W, Tanzi RE, Nairn AC, Greengard P, Gandy SE, Kirino Y (1997) Phosphorylation of Alzheimer $\beta$-amyloid precursor-like proteins. Biochemistry $36: 4646-4649$.

Tanzi RE, Gusella JF, Watkins PC, Bruns GAP, St George-Hyslop P, Van Keuren ML, Patterson D, Pagan S, Kurnit DM, Neve RL (1987) Amyloid $\beta$ protein gene: cDNA, mRNA distribution, and genetic linkage near the Alzheimer's disease. Science 235:880-884.

Tanzi RE, McClatchey AI, Lamperti ED, Villa-komaroff L, Gusella JF, Neve RL (1988) Protease inhibitor domain encoded by an amyloid protein precursor mRNA associated with Alzheimer's disease. Nature 331:528-530.

Tomita S, Kirino Y, Suzuki T (1998a) Cleavage of Alzheimer's amyloid precursor protein by secretases occurs after O-glycosylation of APP in the protein secretory pathway. J Biol Chem 273:6277-6284.

Tomita S, Kirino Y, Suzuki T (1998b) A basic amino acid in the cytoplasmic domain of Alzheimer's $\beta$-amyloid precursor protein (APP) is essential for the cleavage of APP at $\alpha$-site. J Biol Chem 273:19304-19310.

Tomita S, Ozaki T, Taru H, Oguchi S, Takeda S, Yagi Y, Sakiyama S, Kirino Y, Suzuki T (1999) Interaction of a neuron-specific protein containing PDZ domains with Alzheimer's amyloid precursor protein. J Biol Chem 274:2243-2254.

Wainwright MS, Perry BD, Won LA, O'Malley KL, Wang W-Y, Ehrlich ME, Heller A (1995) Immortalized murine striatal neuronal cell lines expressing dopamine receptors and cholinergic properties. J Neurosci 15:676-688.

Waldmann R, Hanson PI, Schulman H (1990) Multifunctional $\mathrm{Ca}^{2+}$ / calmodulin-dependent protein kinase made $\mathrm{Ca}^{2+}$ independent for functional studies. Biochemistry 29:1679-1684.

Walter J, Capell A, Hung AY, Langen H, Schnölzer M, Thinakaran G, Sisodia SS, Selkoe DJ, Haass C (1997) Ectodomain phosphorylation of $\beta$-amyloid precursor protein at two distinct cellular locations. J Biol Chem 272:1896-1903.

Wasco W, Gurubhagavatula S, Paradis MD, Romano DM, Sisodia SS, Hyman BT, Neve RL, Tanzi RE (1993) Isolation and characterization of APLP2 encoding a homologue of the Alzheimer's associated amyloid $\beta$ protein precursor. Nat Genet 5:95-100.

Watanabe T, Sukegawa J, Sukegawa I, Tomita S, Iijima K, Oguchi S, Suzuki T, Nairn AC, Greengard P (1999) A 127-kDa protein (UVDDB) binds to the cytoplasmic domain of the Alzheimer's amyloid precursor protein. J Neurochem 72:549-556.

Zheng P, Eastman J, Pol SV, Pimlikar SW (1998) PAT1, a microtubleinteracting protein, recognizes the basolateral sorting signal of amyloid precursor protein. Proc Natl Acad Sci USA 95:14745-14750. 